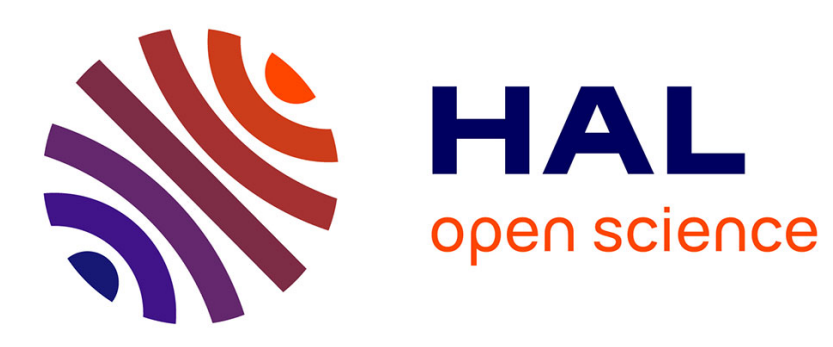

\title{
Humic substances from vermicompost enhance urban lettuce production
}

\author{
Orlando L. Hernandez, Andrés Calderín, Rafael Huelva, Dariellys \\ Martínez-Balmori, Fernando Guridi, Natália O. Aguiar, Fábio L. Olivares, \\ Luciano Pasqualoto Canellas
}

\section{To cite this version:}

Orlando L. Hernandez, Andrés Calderín, Rafael Huelva, Dariellys Martínez-Balmori, Fernando Guridi, et al.. Humic substances from vermicompost enhance urban lettuce production. Agronomy for Sustainable Development, 2015, 35 (1), pp.225-232. 10.1007/s13593-014-0221-x . hal-01284254

\section{HAL Id: hal-01284254 \\ https://hal.science/hal-01284254}

Submitted on 7 Mar 2016

HAL is a multi-disciplinary open access archive for the deposit and dissemination of scientific research documents, whether they are published or not. The documents may come from teaching and research institutions in France or abroad, or from public or private research centers.
L'archive ouverte pluridisciplinaire HAL, est destinée au dépôt et à la diffusion de documents scientifiques de niveau recherche, publiés ou non, émanant des établissements d'enseignement et de recherche français ou étrangers, des laboratoires publics ou privés. 


\title{
Humic substances from vermicompost enhance urban lettuce production
}

\author{
Orlando L. Hernandez • Andrés Calderín • Rafael Huelva • \\ Dariellys Martínez-Balmori • Fernando Guridi • Natália O. Aguiar • \\ Fábio L. Olivares • Luciano Pasqualoto Canellas
}

\begin{abstract}
Accepted: 3 March 2014 / Published online: 29 May 2014
\end{abstract}
(C) INRA and Springer-Verlag France 2014

\begin{abstract}
Urban agriculture is growing worldwide with the growth of cities. Urban agriculture represents about $20 \%$ of Cuban agriculture. In Cuba, urban agriculture is institutionalized and organized with ecological principles. For instance, local agriculture enhances food security and decreases the use of nonrenewable fertilizers. However, organic crop production in urban environments is challenging because of intensive plant nutrient requirements and disease incidence. Here, we tested an innovative technology based on plant growth promoters isolated from vermicompost and applied directly to lettuce leaves. We monitored plant metabolism by measuring the activities of nitrate reductase, an enzyme linked to $\mathrm{N}$ assimilation, and of phenylalanine ammonia lyase, an enzyme linked to plant defense. The experiment was conducted in the organic urban system in Guines, Cuba. We applied liquid humates at 10,15 , or $20 \mathrm{mg} \mathrm{C} \mathrm{L}^{-1}$ once at the seedling stage and again 15 days after transplantation. Our results show that humates at $15 \mathrm{mg} \mathrm{C} \mathrm{L}^{-1}$ shortened by 21 days the lettuce production cycle, allowing early harvesting without changing quality while increasing yields expressed as the number of leaves per plant. Humate application also decreased total carbohydrate, increased protein, increased nitrate uptake, and stimulated nitrate reductase and phenylalanine ammonia lyase in lettuce leaves.
\end{abstract}

O. L. Hernandez $\cdot$ A. Calderín · R. Huelva $\cdot$ D. Martínez-Balmori F. Guridi

Departamento de Química, Facultad de Agronomía, Universidad Agraria de La Habana "Fructuoso Rodríguez Pérez" UNAH, Autopista Nacional Km 231/2, Carretera a Tapaste, San José de las Lajas, Mayabeque, Cuba

N. O. Aguiar · F. L. Olivares · L. P. Canellas $(\triangle)$

Núcleo de Desenvolvimento de Insumos Biológicos para Agricultura, da Universidade Estadual do Norte Fluminense Darcy Ribeiro, Av. Alberto Lamego 2000, Campos dos Goytacazes, Rio de Janeiro 28013-602, Brazil

e-mail: canellas@uenf.br
Keywords Humic substances $\cdot$ Physiological effects Organic agriculture $\cdot$ Urban agriculture $\cdot$ Nitrogen metabolism $\cdot$ Biostimulant

\section{Introduction}

The transition concept in agroecology refers to rapid and sometimes abrupt reorganization of production models that move forward to new complex systems operating within the confines of older structures. The transition in Cuban industrial agriculture toward a model based on organic and agroecological concepts was driven by reduced availability of petrochemicals after the economic breakdown of the Eurasian socialist block at the beginning of the 1990s. The shift gave rise to an urban agriculture program based mainly on the use of vermicompost as a plant growth substrate (Fig. 1). Among the main concerns that became apparent in the first years of this agroecological transition, Claro (2001) emphasized increased incidence of pests and plant nutritional disorders that appeared as crops adapted to pure organic resources as fertilizers. In these circumstances, plant biostimulation compounds have great potential as a technology that can speed up crop system adaptation to new agroecological production models (Canellas et al. 2013).

Vermicompost has been used as growth medium for horticulture because it has a high content of available nutrients and plant growth promoters (Arancon et al. 2004) and it effectively replaces other organic substrates produced through environmentally unfriendly peat extraction (Zaller 2007). Ricci et al. (1995) demonstrated that vermicompost provides $\mathrm{P}, \mathrm{Ca}, \mathrm{Mg}$, and $\mathrm{S}$ at levels equivalent to those in inorganic fertilizers. Moreover, there are good data showing that vermicompost is enriched with humic substances that have the ability to promote plant growth and nutrient uptake (Arancon et al. 2004). For example, Rodda et al. (2006) demonstrated that humates 
Fig. 1 General view of the urban agriculture units $(\mathbf{a}, \mathbf{b})$ strictly based on ecological principles driven by provision of fertilizer through organic residue recycling and a water use economy by lowcost irrigation system device (c); place where our experiment with humate foliar application on lettuce was carried out (d)
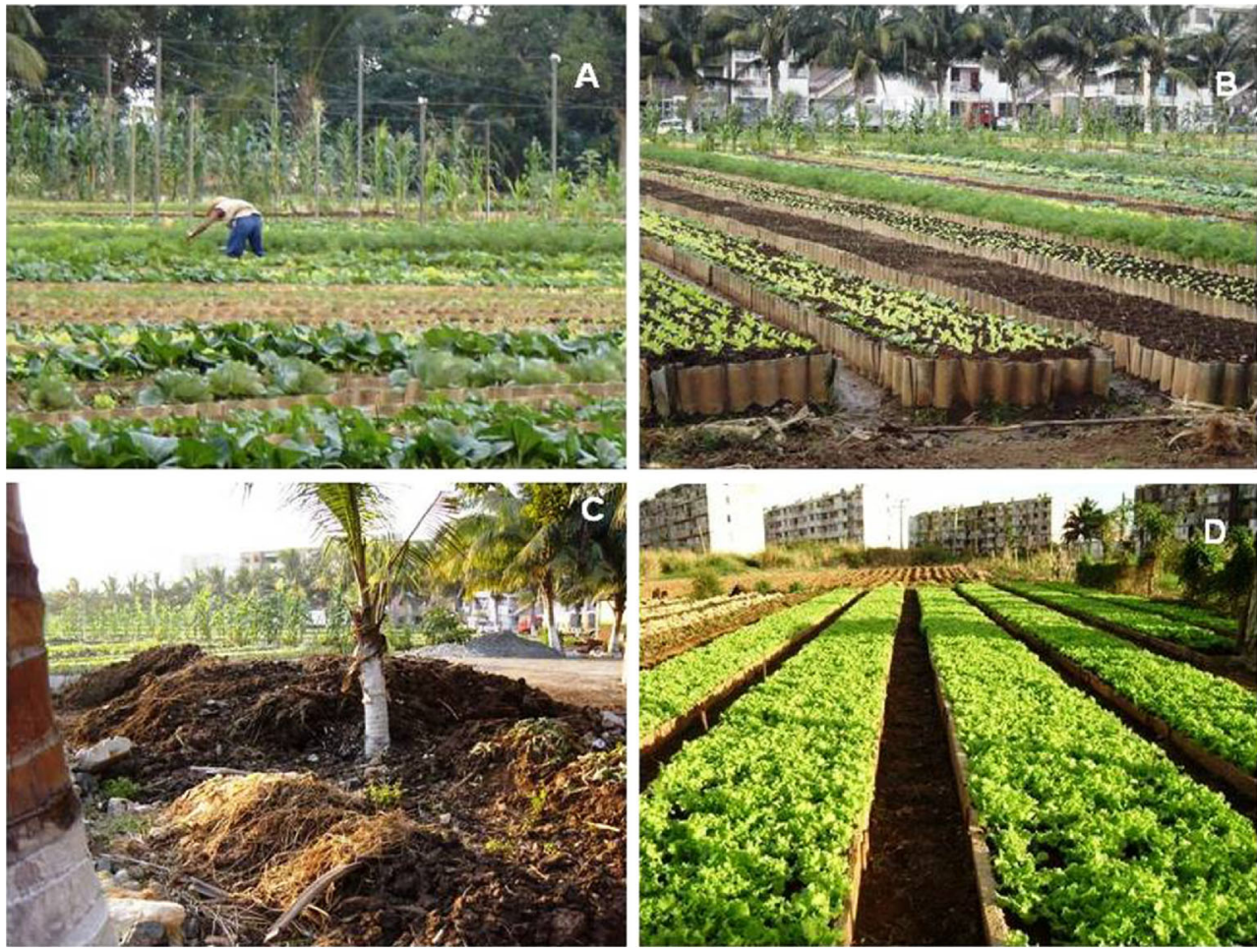

isolated from different vermicomposts promoted lettuce root growth, which in turn increased resistance to stress after transplantation. Increased lateral root emergence was followed by enhance on plasma membrane (PM) $\mathrm{H}^{+}$-ATPase activity. This enzyme couples adenosine triphosphate (ATP) hydrolysis to the $\mathrm{H}^{+}$transport mechanism across cell membranes (Sze et al. 1999). In consequence, the apoplast is acidified and cell walls are loosened, allowing cell elongation in response to internal turgor pressure, thereby favoring increased root growth. Furthermore, activation of $\mathrm{PM} \mathrm{H}$ ATPase also improves plant nutrition through enhancement of the electrochemical proton gradient that drives ion transport across cell membranes via secondary transport systems (Morsomme and Boutry 2000). Thus, the plant growth promotion benefits of humic substances isolated from vermicompost are well documented (Canellas et al. 2002, Nardi et al. 2009; Aguiar et al. 2013).

High susceptibility to plant disease is a major challenge for organic urban food production. There are approximately 75 different diseases in lettuce (Lopes and Quezado-Duval 1998) and since the leaves are consumed fresh, disease resistance is essential for successful cultivation. Edwards et al. (2006) reported that plants treated with humates became more resistant to some forms of disease. Schiavon et al. (2010) reported changes in secondary metabolism in maize seedlings treated with humic substances isolated from vermicompost. These authors observed increased activity and expression of phenylalanine ammonia lyase (PAL) following humic acid treatment. This enzyme catalyzes the first step in the phenolic biosynthesis pathway converting phenylalanine to trans-cinnamic acid. Among secondary metabolites, phenolic compounds (e.g., flavonoids and phenylpropanoids) are widely recognized as protective agents against a range of biotic and abiotic stresses (Dixon and Paiva 1995).

The aim of this work was to evaluate the benefits of the foliar application of humates (isolated from vermicompost) in organic lettuce production within an urban organic production system. Changes induced in foliar metabolism following treatment were monitored and related to shortening of the production cycle and improved leaf formation in treated plants. Reduced space occupancy by crops over time is essential for successful urban organic farming production.

\section{Materials and methods}

The field trial was carried out in an organic lettuce production unit operated by the Urban Agriculture Movement in Guines, southern Mayabeque State, Cuba. The cultivar Black Seed Simpson was sown, and germinated plants were cultivated from September to December, a period of the year considered ideal for lettuce cultivation in this location. Lettuces were grown in a bed 40-m long and 1-m wide; plants were spaced at intervals of $0.15 \mathrm{~m}$, and rows were $0.25 \mathrm{~m}$ apart. The beds comprised a mixture of soil and cattle manure vermicompost $(3: 1, v / v)$; the $\mathrm{pH}$ in water was 7.03 . We measured an organic carbon content of $306 \mathrm{~g} \mathrm{~kg}^{-1}$ by dicromatometry (following

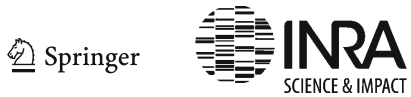


Yeomans and Bremner 1988). Concentrations of $\mathrm{K}^{+}, \mathrm{Ca}^{2+}$, $\mathrm{Mg}^{2+}$, and $\mathrm{Na}^{+}$measured by atomic absorption spectrometry after extraction with $1 \mathrm{~mol} \mathrm{~L}^{-1} \mathrm{KCl}$ were 5.7, 149.0, 20.0, and $20.0 \mathrm{mmol} \mathrm{kg}{ }^{-1}$, respectively. Available P concentration (measured colorimetrically after Mehlich 1 extraction) was $1,388 \mathrm{mg} \mathrm{kg}^{-1}$. The $\mathrm{K}^{+}$humates were obtained from cattle manure vermicompost with a $0.1 \mathrm{~mol} \mathrm{~L}^{-1} \mathrm{KOH}$ ratio of 1:10 $(w / v)$. The total organic carbon measured according to Yeomans and Bremner (1988) was $82.5 \mathrm{mM} \mathrm{C} \mathrm{L}^{-1}$. Selected humate characteristics on a dry weight basis were as follows: total organic carbon, $36.2 \mathrm{~g} \mathrm{~kg}^{-1}$; total humic substances, $25.8 \mathrm{~g}^{-1}$; humic acids, $12.8 \mathrm{~g} \mathrm{~kg}^{-1}$; fulvic acids, $13.0 \mathrm{~g} \mathrm{~kg}^{-1}$; $\mathrm{pH} 8.73$; electrical conductivity, $5.81 \mathrm{mS} \mathrm{cm}^{-1}$; total nitrogen content, $1.3 \mathrm{~g} \mathrm{~kg}^{-1}$; total $\mathrm{P}$ content (as $\left.\mathrm{P}_{2} \mathrm{O}_{5}\right), 10.7 \mathrm{~g} \mathrm{~kg}^{-1}$; and ash content, $3 \%$. The $\mathrm{C}$ functionality distribution was determined by NMR spectroscopy using solid-state crosspolarization with magic angle spinning (CP-MAS) on samples from humates that had been freeze-dried. The spectra were acquired with a Bruker Avance $500 \mathrm{MHz}$ (Bruker, Karlsruhe, Germany) spectrometer equipped with a 4-mm-wide bore MAS probe operating at $13 \mathrm{C}$ and $1 \mathrm{H}$ frequencies of 125 and $500 \mathrm{MHz}$, respectively. The samples $(260 \mathrm{mg})$ were packed into 4-mm zirconia rotors with Kel-F caps and spun at $13 \pm$ $1 \mathrm{kHz}$. The spectra were acquired by the ramped-CP/MAS method with linear amplitude variation of the $1 \mathrm{H}$ pulse. The measurements were made using a cross-polarization time of $1.0 \mathrm{~ms}$, an acquisition time of $25 \mathrm{~ms}$, a cycle delay of $2 \mathrm{~s}$, and high-power two-pulse phase modulation (TPPM) proton decoupling of $70 \mathrm{kHz}$. Bruker Topspin 1.3 software (Bruker Biospin) was used to collect and process the spectra. Free induction decays (FIDs) were transformed by applying a 4-k zero filling and a line broadening of $75 \mathrm{~Hz}$. The spectra (Fig. 2) were area-normalized and integrated in the following ${ }^{13} \mathrm{C}$ chemical shift intervals: $190-160$ ppm (carbonyls of ketones, quinines, aldehydes, and carboxyls), $5 \%$; 160 $140 \mathrm{ppm}$ (phenols and substituted aromatic carbons), $7 \%$; 140-110 ppm (unsubstituted aromatic carbons and olefinic

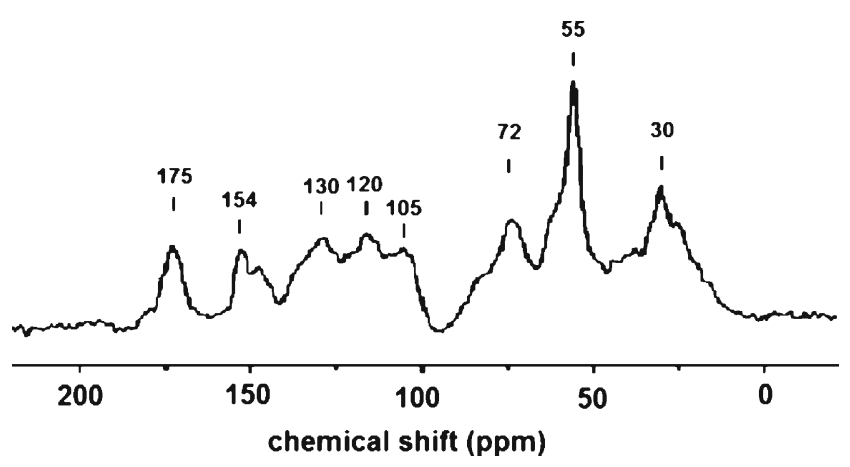

Fig. 2 Cross-polarization with rotation on "magic angle" ${ }^{13} \mathrm{C}$ resonance nuclear magnetic resonance (CP/MAS ${ }^{13} \mathrm{C}$ NMR) spectrum of freezedried humate samples. The spectrum shows strong absorption at $55 \mathrm{ppm}$ related to the presence of methoxy groups probably on aromatic rings of guaiacyl and siringyl units of lignin structures systems carbons), $20 \%$; 110-95 ppm (anomeric carbons), $6 \%$; 65$95 \mathrm{ppm}(\mathrm{O}$-alkyl systems, such as alcohols and ethers), $12 \%$; 65-45 ppm ( $N$-alkyl groups and complex aliphatic carbons), $22 \%$; and 45-0 ppm (alkyl carbon, mainly $\mathrm{CH}_{2}$ and $\mathrm{CH}_{3}$ ), $28 \%$.

$\mathrm{K}^{+}$humates were applied to lettuce leaves (using a manual costal sprayer) 10 and 15 days after transplantation at concentrations equivalent to $0,10,15$, and $20 \mathrm{mg} \mathrm{C} \mathrm{L}^{-1}$; the application rate of each solution was $500 \mathrm{~L} \mathrm{ha}^{-1}$. The concentrations of humates corresponded to aqueous solutions with similar concentrations of $\mathrm{K}^{+}$at $\mathrm{pH}$ 7.0. The applications at 10 and 15 days were visually determined by the leaf drip point.

Leaf biochemical analyses were performed 5 days after the last humate application. Photosynthetic pigments were analyzed following Plumer (1981); we homogenized $250 \mathrm{mg}$ of fresh leaves in $85 \%$ acetone, filtered the extract through Whatman ${ }^{\circledR} 42$ filter paper, and colorimetrically determined concentrations (as $\mu \mathrm{g} \mathrm{mL}^{-1}$ acetone extract) from absorbances at 470, 646, and $663 \mathrm{~nm}$. Total carbohydrate contents were determined following the procedure of Tanford (1961). Glucose was used as the calibration standard, and concentrations were expressed as micrograms of glucose per gram of fresh mass. Total protein content was determined by using the Bradford (1976) method and expressed as micrograms of protein per gram of fresh mass. Foliar $\mathrm{NO}_{3}{ }^{-}$content was determined (following Cataldo and Mingguang 1975) by UV-vis spectrometry at $410 \mathrm{~nm}$ using standard $\mathrm{KNO}_{3}$ (Sigma Aldrich) for the calibration curve; the concentration was expressed as milligrams of $\mathrm{NO}_{3}{ }^{-}$per kilogram of fresh mass. Nitrate reductase (NR) activity (EC:1.6.6.1) in vivo was performed (Jaworsky 1971) on foliar disks cut from the most recently completely expanded leaves. Fresh tissues were incubated at $30{ }^{\circ} \mathrm{C}$ for $1 \mathrm{~h}$. Aliquots were obtained during incubation, and the reaction was terminated with sulfanylamide and $\mathrm{N}$-naftiletilendiamida (NNDA). Absorbance was measured at $540 \mathrm{~nm}$ for $\mathrm{NO}_{2}^{-}$determination. A standard curve was constructed using $\mathrm{Na}_{2} \mathrm{NO}_{2}$ (Sigma) as a standard solution, and NR activity was expressed as millimoles of $\mathrm{NO}_{2}{ }^{-}$per hour per gram of fresh mass. The activity of phenylalanine ammonia lyase (PAL) (EC:4.3.1.5) was determined according to Schiavon et al. (2010), with a few modifications, as follows: $0.5 \mathrm{~g}$ of foliar fresh tissues was homogenized in an ice bath with acetone followed by addition of $2 \mathrm{~mL}$ of borate buffer $\left(0.1 \mathrm{~mol} \mathrm{~L}^{-1} \mathrm{H}_{3} \mathrm{BO}_{3}\right.$ and $0.1 \mathrm{~mol} \mathrm{~L}^{-1}$ $\mathrm{Na}_{2} \mathrm{~B}_{4} \mathrm{O}_{7} 10 \mathrm{H}_{2} \mathrm{O}$ ), giving a final $\mathrm{pH}$ of 8.8 . One milliliter aliquots of extract were combined with $0.9 \mathrm{~mL}$ of L-phenylalanine and incubated at $40{ }^{\circ} \mathrm{C}$ for $30 \mathrm{~min}$. We then added $250 \mu \mathrm{L}$ of $5 \mathrm{~mol} \mathrm{~L}^{-1} \mathrm{HCL}$ and inserted the tubes in an ice bath for $30 \mathrm{~min}$. After this time, we added $5 \mathrm{~mL}$ of $\mathrm{H}_{2} \mathrm{O}$ and allowed the mixture to stand for $15 \mathrm{~min}$. The suspension was filtered; we then read absorbances at $290 \mathrm{~nm}$. Cinamic acid (Sigma) was used for the standard curve, and PAL 
activity was expressed as millimoles of cinamic acid per minute per gram of protein.

Data were analyzed as a randomized block design with three replications of each treatment. Each replicate comprised 20 leaves collected for biochemical measurements. We used Origin software to test the significance of the regression analyses.

\section{Results and discussion}

There was a remarkable decrease in the duration of the lettuce production cycle when humates were applied as a foliar spray (Fig. 3a) with dose-dependence matched to the best performance. Thus, for plants treated with a humate dose of $15 \mathrm{mg}$

days after transplant untilharvest
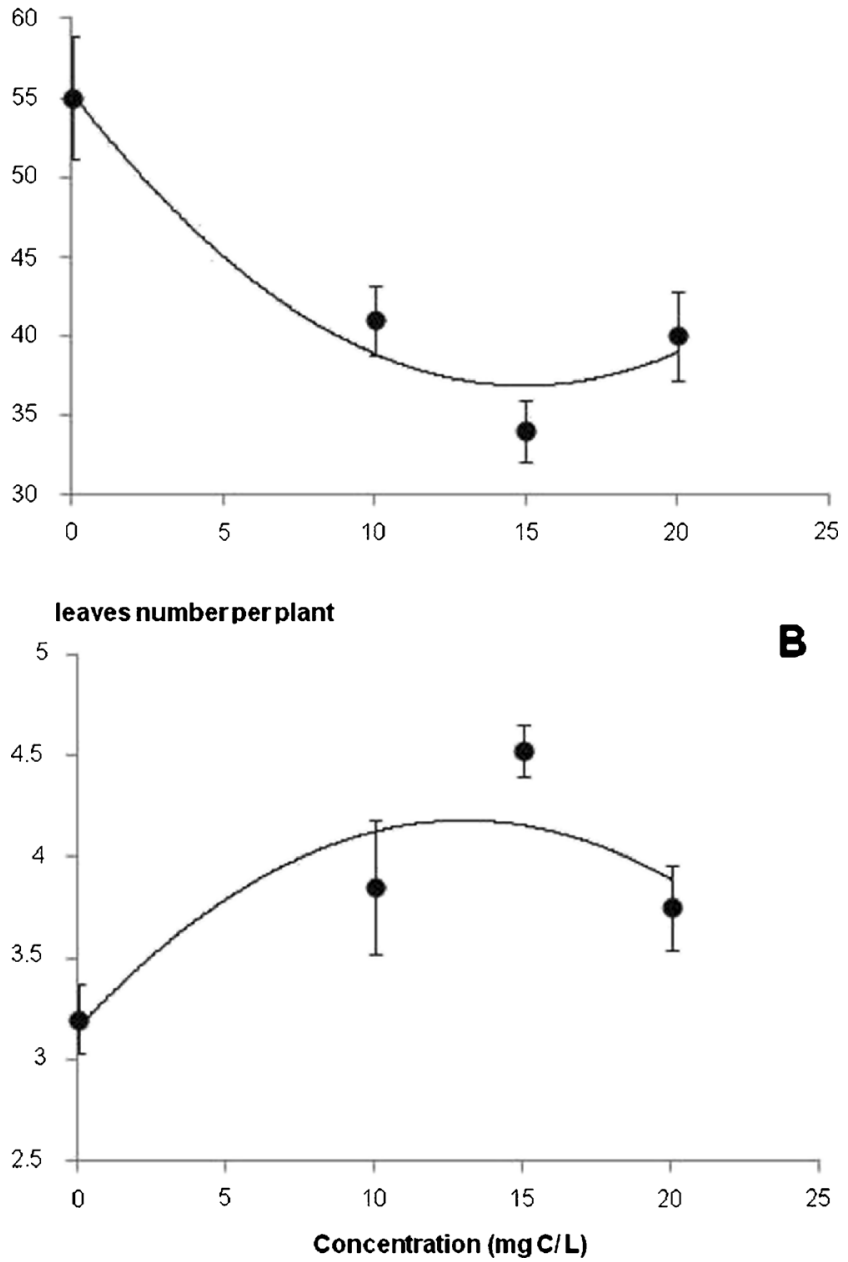

Fig. 3 a Duration of time (days) from transplantation through harvest of lettuces treated with humates at different concentrations. The quadratic model fit was significant $\left(R^{2}=0.94 ; P<0.001 ; y=0.0827 \mathrm{x}^{2}-2.47 \mathrm{x}+\right.$ 55.35 ); at a humate concentration of $15 \mathrm{mg} \mathrm{C} \mathrm{L}^{-1}$, harvest was anticipated by 21 days. b Number of leaves 20 days after transplantation. The quadratic model fit was significant $\left(y=-0.006 \mathrm{x}^{2}+0.16 \mathrm{x}+3.15 ; R^{2}=\right.$ $0.74 ; P<0.001$ ); at a humate concentration of $15 \mathrm{mg} \mathrm{C} \mathrm{L}^{-1}$, the number of leaves produced was $\sim 28 \%$ higher than in controls
$\mathrm{C} \mathrm{L}^{-1}$, the period between transplant and harvest was shortened in 21 days. The period between transplant and harvest was slightly more protracted ( $6 \pm 0.5$ days) for plants treated with lowest and highest humate doses (10 and $20 \mathrm{mg} \mathrm{C} \mathrm{L}^{-1}$, respectively), but all humate doses tested reduced time to harvest in comparison with control plants. In addition, humate application increased leaf number per plant (Fig. 3b). The humate effect on lettuce growth promotion had corollary benefits, such as increased yields (higher number of leaves), better appearance of leaves (a positive impact when selling directly to consumers) and better space utilization, which may be a key factor in urban agriculture design.

Morphological responses to humate application were associated with physiological responses. Total chlorophyll content and carotenoid pigments were not modified by humate application (Fig. 4a), whereas previous tests with humic substances have demonstrated either increases or decreases in contents of leaf pigments in response to treatments, suggesting influences
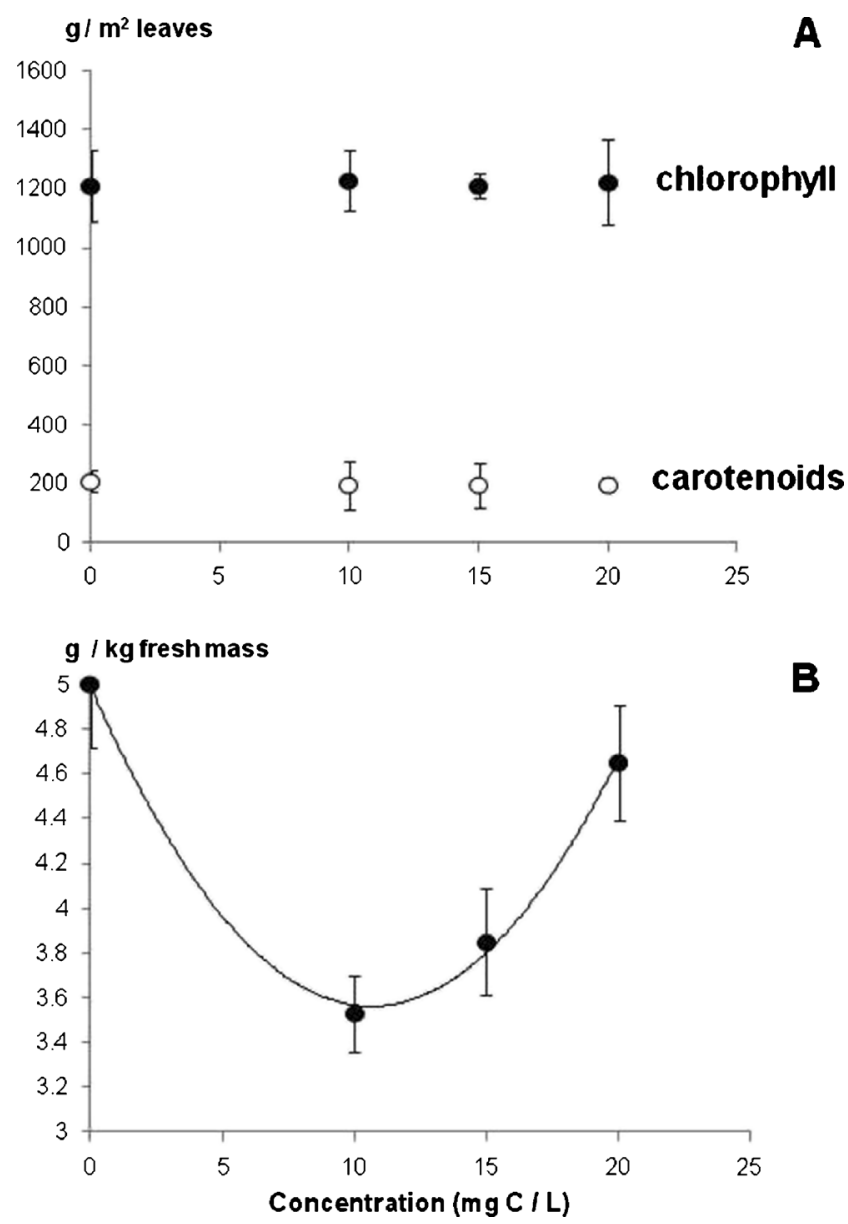

Fig. 4 a Chlorophyll and total carotenoids contents were not affected by the humate application to lettuce leaves; visual appearance of leaves was not negatively affected by spraying. b Total carbohydrate content in lettuce leaves 20 days after transplantation was reduced to different extents by application of different humate concentrations. The quadratic model fit was significant $\left(y=0.13 \mathrm{x}^{2}-0.27 \mathrm{x}+4.99 ; R^{2}=0.99 ; P<0.001\right)$ 
of age, plant species, sources, and concentrations of humic materials on plant responses. However, the relationship between leaf pigment concentration and plant production is neither simple nor linear (Šesták 1966). Nevertheless, the intensity of green pigmentation in market lettuces is not relevant for commercial success, and since we found no effects of humate application on pigmentation, application of humate fertilizer is unlikely to detract from marketability.

Total carbohydrate content decreased in leaves treated with humic substances (Fig. 4b), indicating that treatments changed source-sink relationship in the lettuces. The relocation of fixed carbon (as reduced sugars) to the root system and its subsequent incorporation into structural macromolecules like proteins to meet the demands of accelerated plant growth may provide a partial explanation for decreases in total carbohydrate content in lettuce leaves (in agreement with Fig. 3). Pizzeghello et al. (2001) found increased variability in invertase activity stimulation among plants treated with different humic substances. This enzyme is associated with sugar metabolism, and its activity increased by 14 to $190 \%$ in comparison with control plants not treated with humic substances. Canellas et al. (2013) detected a $62 \%$ reduction in the free carbohydrate content of maize plants treated with humates in comparison with untreated controls; the responses to treatment included decreases in glucose and fructose content. Humic substances modulate carbon and nitrogen metabolism by increasing the activity of enzymes involved in glycolysis, the Krebs cycle, and $\mathrm{N}$ assimilation (Nardi et al. 2007). Nardi et al. (2009) reported that humic substances may inhibit the activity of glucokinase, phosphoglucose isomerase, aldolase, and pyruvate kinase (enzymes that are involved in glucose metabolism) and demonstrated that the effect of humic substances on the activities of enzymes related to the glycolysis pathway in maize seedlings may be stimulatory or inhibitory, depending on the concentration and chemical characteristics of the humic materials.

Total protein content also increased in leaves we treated with humates (Fig. 5a); the relationship between protein content and humic concentration was best described by a quadratic regression. Generally, when humates were applied at lower concentrations, plant responded by increasing protein content and reducing carbohydrate content (Fig. 4b). Canellas et al. (2013) and others works (Nardi et al. 2009 and references therein) have also reported a stimulation in protein content following application of humic substances. Since nitrate content and enzymes linked to $\mathrm{N}$ assimilation were also stimulated by our treatments (Fig. 5b, c), it is possible that the reduction in total carbohydrate content is explained by the use of these metabolites as sources of energy and structural carbon to sustain growth and enhance $\mathrm{N}$ metabolism.

Nitrate uptake by roots may be favored by the enhancement of root systems or elevated active transport. Furthermore, $\mathrm{NO}_{3}{ }^{-}$uptake requires energy, and anion transport is performed by proton simport $\left(2 \mathrm{H}^{+}: \mathrm{NO}_{3}{ }^{-}\right)$(Glass et al. 1992). Proton transport induction to the apoplast has been demonstrated in maize seedlings by Canellas et al. (2002) and in lettuce by Rodda et al. (2006). Quaggiotti et al. (2004) detected enhanced nitrate uptake in seedlings treated with humic substances in addition to induction of expression in $\mathrm{Zm} \mathrm{Nr2.1}$, which is a gene family that encodes high-affinity $\mathrm{NO}_{3}{ }^{-}$transporters. Although we performed no direct measures of nitrate transporters, nitrate uptake and elevated induction of NR activity allow us to conclude that a more efficient $\mathrm{N}-\mathrm{NO}_{3}{ }^{-}$ acquisition operated in plants treated with humates at a concentration of $15 \mathrm{mg} \mathrm{L}^{-1}$. Canellas et al. (2013) also determined that soluble humates at concentrations of 10 and $20 \mathrm{mg} \mathrm{C} \mathrm{L}^{-1}$ stimulate NR activity by 52 and $18 \%$, respectively, in comparison with control maize plants. Nitrate reductase is generally induced by the substrate's presence, and since $\mathrm{NO}_{3}{ }^{-}$ content was elevated in our humate treatments (Fig. 5b, c), we believe that nitrate reductase was also enhanced.

We noted a low incidence of disease during the lettuce growing stages. The healthy appearance of leaves treated with humates was correlated with significant changes in secondary metabolism. The phenylalanine ammonia lyase activity of leaves is plotted in Fig. 5d. Elevated PAL activity was induced by humates at a concentration of $15 \mathrm{mg} \mathrm{C} \mathrm{L}^{-1}$. This effect was correlated with measures of highest total protein contents in plants subjected to this treatment, suggesting that there was metabolic synthesis of this enzyme precursor. Erytrose-4-P and phosphoenolpyruvic acid are precursors for a sequence of reactions leading to synthesis of shikimic acid and their derivates (phenylalanine, tryptophan, and tyrosine). The lowest content of carbohydrates in plants treated with humates (Fig. 4b) may be, at least in part, associated with the biosynthesis of secondary compounds. Phenylalanine ammonia lyase (EC 4.3.1.5) is located at the point branch between primary and secondary metabolism, and its reaction catalyzes an important step in the regulation of phenolic compound synthesis, which is an important chemical strategy in plant defense responses against herbivores (Saldana et al. 2007). It is possible that some of the compounds present in the complex and heterogeneous assemblage that humates form in solution may act as elicitors and inducers of phenylalanine ammonia lyase activity. Schiavon et al. (2010) were the first to report that humic substances may modulate secondary metabolism by regulation of PAL expression.

The main effect of humic substances on plant growth is increased root formation (Nardi et al. 2009); foliar application brings benefits to the production of crops such as olives, wheat, tomato, papaya, maize, creeping bentgrass, etc. (Femández-Escobar et al. 1996; Cooper et al. 1998; Delfine et al. 2005; Zaller 2006; Yildirim 2007; Karakurt et al. 2009; Cavalcante et al. 2011; Canellas et al. 2013). The responses in growth and yield have been attributed to a number of mechanisms that include enhancement of chlorophyll content, 

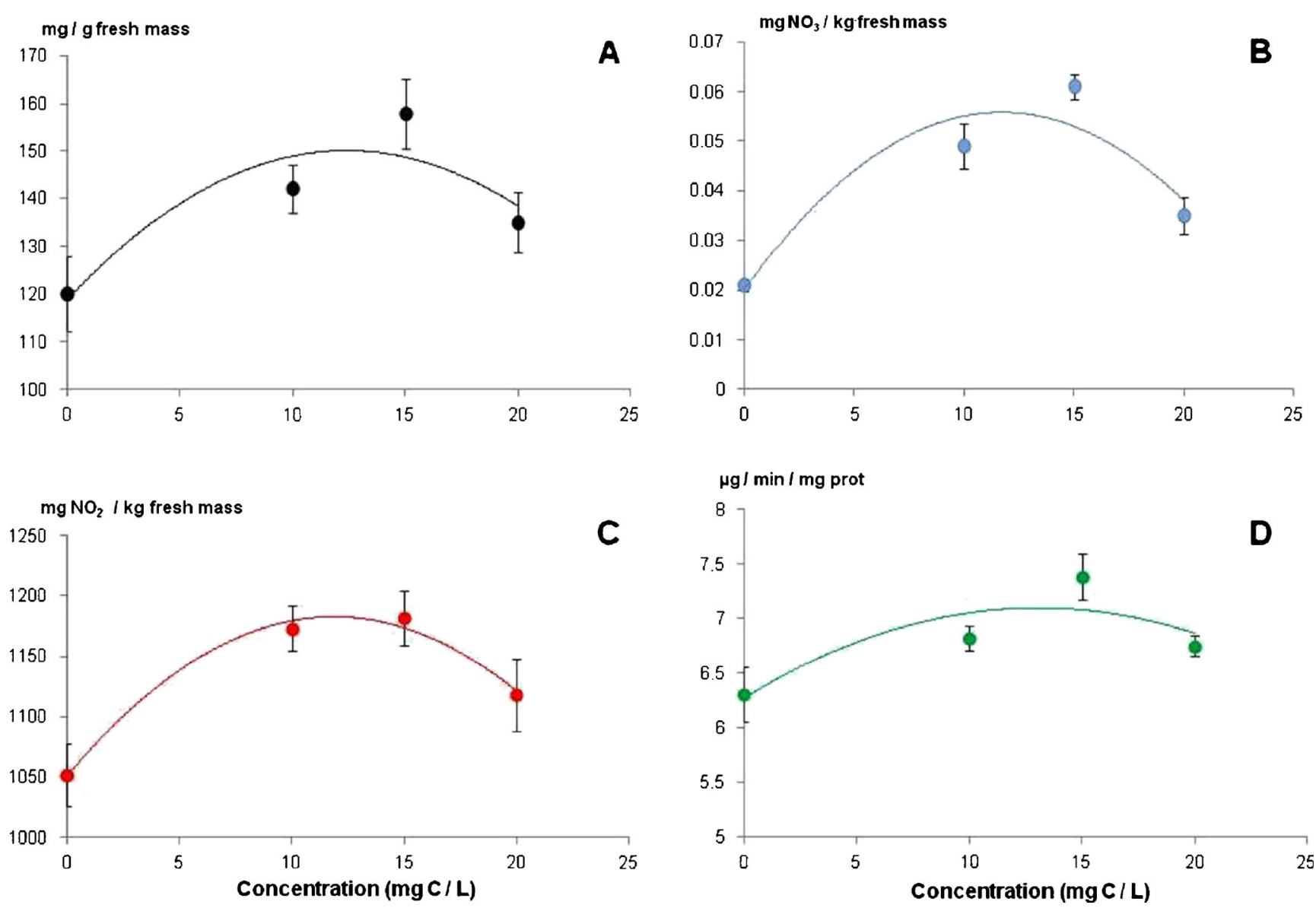

Fig. 5 Total protein content (a), foliar nitrate content (b), nitrate reductase (c), and phenylalanine ammonia lyase activities (d) in lettuce leaves 20 days after transplantation and treatment with different humate concentrations. Primary metabolism was affected by humate application: nitrate

and protein contents in leaves increased. Phenylalanine ammonia lyase activity has been previously linked to plant defense responses, demonstrating an important link between the humate response and disease control

ribulose $1-5$, biphosphate carboxylase activity, stomatal conductance, accumulation of macro- and micronutrients in leaves, changes in carbohydrates metabolism, and suppression of some diseases. For example, Tejada et al. (2008) demonstrated enhanced fruit production and tomato quality when liquid leaches from vermicompost were applied as foliar sprays and showed that best responses were obtained with highest contents of humic substances in the leachate. They attribute these responses to increases in the uptake of N, P, and $\mathrm{K}$ and increases in chlorophyll concentration. Similar results on growth, yield, and quality of strawberry were obtained by Singh et al. (2010) following foliar application of vermicompost leachates rich in soluble humic substances. We did not detect changes in the pigment content of lettuce leaves in response to treatments but noted a marked effect on enzymes linked to $\mathrm{N}$ assimilation, carbohydrates metabolism, and plant defense responses. There is a time lag between organic fertilizer application and nutrient availability to plants because the fertilizer must be mineralized before nutrients are taken up by plant roots. Our foliar application of humates derived from vermicompost activated leaf metabolism and accelerated the development of plants by shortening the production cycle without reducing the commercial quality of the plants. This combination of responses will be especially important for urban agriculture where space is a limiting factor. Another important response that we observed following foliar application of humates was the stimulation of phenylalanine ammonia lyase activities in leaves.

Studies on vermicomposts have demonstrated that the product is a well-stabilized, esthetically pleasing, finely divided peat-like material with excellent structure, porosity, aeration, drainage, enhanced moisture holding capacity, and a capability for enhancing plant growth (Ali et al. 2007). According to Warman and AngLopez (2010), the enhancement of plant growth by mature vermicompost may not only be a nutritional response but may also result from the content of biologically active plant growth-influencing substances (Arancon et al. 2004; Aguiar et al. 2013).

Importantly, we have demonstrated that the application of soluble humic substances as a foliar spray suspension of 
mixed, heterogeneous, and small organic molecules is appropriate for the practice of urban organic farming. The fundamentals of agroecology include the maintenance of high levels of biodiversity in diversified agricultural systems; this ensures resiliency and robustness against pests and diseases. Nutrient cycling and the provision of organic matter as a slow release source of plant nutrients are also fundamental to the practice of this form of organic farming. The urban environment is radically different from natural agrosystems, and production is based on an organic principle that requires rapid plant adaptation. Traditional knowledge of peasants is another mainstay of the agroecological concept. Insertion of urban agriculture into this context is not a simple issue, and there remains many items for critical discussion. According Altieri et al. (2012), Cuba's achievements in urban agriculture have grown to truly remarkable proportions: 383,000 urban farmers cultivate more than 50,000 ha of otherwise unused land and produce around 4 million tons of vegetables annually, enough to supply $40-60 \%$ or more of all the fresh vegetables in cities such as Havana, Villa Clara, and Guines. This program is an important contributor toward food security and independence from external nutrient sources. Our present understanding shows that the combination of new scientific knowledge, preexisting information on molecular and cellular processes, and the design of plant biostimulator products based on humic substances isolated from recycled sources of organic matter will likely function as an important technological tool in the consolidation of urban production.

\section{Conclusion}

Foliar application of soluble humates isolated from vermicompost promoted organic lettuce yields. Changes in lettuce metabolism occurred in plants treated with humates, including decreased total carbohydrate content, increased total protein content in leaves, and induction of nitrate reductase and phenylalanine ammonia lyase activity, which in combination accelerated the production cycle. Thus, we have described one mechanism of plant promotion using soluble humic substances; the procedures we used will likely represent an important technological component of improved urban agriculture.

\footnotetext{
Acknowledgments We thank CAPES/MES (AUX-PE 1760/2010) for making possible the international scientific cooperation between Brazil and Cuba. FAPERJ, CNPq, and INCT for Biological Nitrogen Fixation provided financial support. This paper is written in memory of Orlando Hernandez.
}

\section{References}

Aguiar NO, Olivares FL, Novotny EH, Dobbss LB, Balmori DM, SantosJúnior LG, Chagas JG, Façanha AR, Canellas LP (2013) Bioactivity of humic acids isolated from vermicomposts at different maturation stages. Plant Soil 362:161-174. doi:10.1007/s11104-012-1277-5

Ali M, Griffiths AJ, Williams KP, Jones DL (2007) Evaluating the growth characteristics of lettuce in vermicompost and green waste compost. Eur J Soil Biol 43:S316-S319. doi:10.1016/j.ejsobi.2007.08.045

Altieri MA, Funes-Monzote FR, Petersen P (2012) Agroecologically efficient agricultural systems for smallholder farmers: contributions to food sovereignty. Agron Sustain Dev 32:1-13. doi:10.1007/ s13593-011-0065-6

Arancon NQ, Edwards CA, Atiyeh R, Metzger JD (2004) Effects of vermicomposts produced from food waste on the growth and yields of greenhouse peppers. Biores Technol 93:139-144. doi:10.1016/j. biortech.2003.10.015

Bradford MM (1976) A rapid and sensitive method for the quantification of micrograms quantities of protein utilizing the principle of protein-dye binding. Anal Biochem 72:248-254

Canellas LP, Okorokova-Façanha A, Olivares FL, Façanha AR (2002) Humic acids isolated from earthworm compost enhance root elongation, lateral root emergence, and plasma membrane $\mathrm{H}^{+}$-ATPase activity in maize roots. Plant Physiol 130:1951-1957. doi:10.1104/ pp. 007088

Canellas LP, Martinez-Balmori D, Médici LO, Aguiar NO, Campostrini E, Rosa RCC, Façanha AR, Olivares FL (2013) A combination of humic substances and Herbaspirillum seropedicae inoculation enhances the growth of maize (Zea mays L.). Plant Soil 366:119-132. doi:10.1007/s11104-012-1382-5

Cataldo D, Mingguang AR (1975) Rapid colorimetric determination of nitrate in plant tissue by nitration of salicylic acid. Commun Soil Sci Plant Anal 6:71-90. doi:10.1080/00103624.2012.631417

Cavalcante IHL, Silva RRS DA, Albano FG, Lima FN, Marques AS (2011) Foliar spray of humic substances on seedling production of papaya. JAgron 10(4):118-122

Claro SA (2001) Referenciais tecnológicos para a agricultura familiar ecológica: a experiência da região Centro-Serra do Rio Grande do Sul. Emater/RS-Ascar, Porto Alegre, p 75p

Cooper RJ, Liu C, Fisher DS (1998) Influence of humic substances on rooting and nutrient content of creeping bentgrass. Crop Sci 38(6): 1639-1644. doi:10.2135/cropsci1998.0011183X003800060037x

Delfine S, Tognetti R, Desiderio R, Alvino A (2005) Effect of foliar application of $\mathrm{N}$ and humic acids on growth and yield of durum wheat. Agron Sustain Dev 25:183-191. doi:10.1051/agro:2005017

Dixon RA, Paiva NL (1995) Stress-induced phenylpropanoid metabolism. Plant Cell 7:1085-1097. doi:10.1105/tpc.7.7.1085

Edwards CA, Arancon NQ, Graytak S (2006) Effects of vermicompost teas on plant growth and disease. Biocycle 47:28-31

Femández-Escobar R, Benlloch M, Barranco D, Duefias A, Gutérrez Ganán JA (1996) Response of olive trees to folk application of humic substances extracted from leonardite. Sci Hort 66: 191-200

Glass ADM, Shaff JE, Kochian LV (1992) Studies on the uptake of nitrate in barley. Electrophysiology. Plant Physiol 99:456-463. doi:10. 1104/pp. 99.2.456

Jaworsky EG (1971) Nitrate reductase assay in intact plant tissues. Biochem Biophys Res Commun 43:1274-1279. doi:10.1016/ S0006-291X(71)80010-4

Karakurt Y, Unlu H, Unlu H, Huseyin Padem H (2009) The influence of foliar and soil fertilization of humic acid on yield and quality of pepper. Acta Agric Scand Sect B Soil Plant Sci 59(3):233-237. doi: 10.1080/09064710802022952

Lopes CA, Quezado-Duval AM (1998) Doenças da alface. Embrapa Hortaliças, Brasília, p 18p 
Morsomme P, Boutry M (2000) The plant plasma-membrane $\mathrm{H}^{+}$-ATPase: structure, function and regulation. Biochim Biophys Acta 1465:116. doi:10.1016/S0005-2736(00)00128-0

Nardi S, Muscolo A, Vaccaro S, Baiano S, Spaccini R, Piccolo A (2007) Relationship between molecular characteristics of soil humic fractions and glycolytic pathway and Krebs cycle in maize seedlings. Soil Biol Biochem 39(12):3138-3146. doi:10.1016/ j.soilbio.2007.07.006

Nardi S, Carletti P, Pizzeghello D, Muscolo A (2009) A biological activities of humic substances. In: Senesi N, Xing B, Huang P (eds) Biophysico-chemical processes involving natural non living organic matter in environmental systems. Wiley, New Jersey, pp 305-340

Pizzeghello D, Nicolini G, Nardi S (2001) Hormone-like activity of humic substances in Fagus sylvatica forests. New Phytol 151(3): 647-657. doi:10.1046/j.0028-646x.2001.00223.x

Plummer DT (1981) Introducción a la bioquímica práctica. http://www. bioquimica.dogsleep.net/Laboratorio/Plummer. Accessed 12 august 2012

Quaggiotti S, Ruperti B, Pizzeghello D, Francioso O, Tugnoli V, Nardi, S (2004) Effect of low molecular size humic substances on nitrate uptake and expression of genes involved in nitrate transport in maize (Zea mays L.). J Exp Bot 55:803-813. doi:10.1093/jxb/erh085

Ricci MSF, Casali VW, Cardoso AA, Ruiz HA (1995) Teores de nutrientes em duas cultivares de alface adubadas com composto orgânico. Pesq Agropec Bras 30:1035-1039. doi:10.1590/S010205362006000200004

Rodda MRC, Canellas LP, Façanha AR, Zandonadi DB, Guerra JGM, Almeida DL, Santos GA (2006) Estímulo no crescimento e na hidrólise de ATP em raízes de alface tratadas com humatos de vermicomposto: I - efeito da concentração. R Bras Ci Solo 30: 649-656. doi:10.1590/S0100-06832006000400006

Saldana LH, Rivera-Hinojosa R, Colinas-León MT (2007) Fenoles, peroxidasa y fenilalanina amonio-lyasa: su relación con la resistencia genética de clones de papa (Solamun tuberosum L.) contra el tizón tardío (Phytophthora infestans Mont. De Bary). Agrociencia 41:479-489
Schiavon M, Pizzeghello D, Muscolo A, Vaccaro S, Francioso O, Nardi S (2010) High molecular size humic substances enhance phenylpropanoid metabolism in maize (Zea mays L.). J Chem Ecol 36:662-669. doi:10.1007/s10886-010-9790-6

Šesták Z (1966) Limitations for finding a linear relationship between chlorophyll content and photosynthetic activity. Biol Plant 8:336346

Singh R, Gupta RK, Patil RT, Sharma RR, Asrey R, Kumar A, Jangra KK (2010) Sequential foliar application of vermicompost leachates improves marketable fruit yield and quality of strawberry (Fragaria $\mathrm{x}$ ananassa Duch.). Sci Hort 124:34-39. doi:10.1016/j.scienta.2009. 12.002

Sze H, Li X, Palmgren MG (1999) Energization of plant cell membranes by $\mathrm{H}^{+}$-pumping ATPases: regulation and biosynthesis. Plant Cell 11: 677-689. doi:10.1105/tpc.11.4.677

Tanford C (1961) Physical chemistry of macromolecules. Wiley, New York, p 371p

Tejada M, Gonzalez JL, Hernandez MT, Garcia C (2008) Agricultural use of leachates obtained from two different vermicomposting processes. Biores Technol 99:6228-6232. doi:10.1016/j.biortech.2007.12.031

Warman PR, Anglopez MJ (2010) Vermicompost derived from different feedstocks as a plant growth medium. Biores Technol 101:4479 4483. doi:10.1016/j.biortech.2010.01.098

Yeomans JC, Bremner J (1988) A rapid and precise method for routine determination of organic carbon in soil. Commun Soil Sci Plant Anal 19:1467-1476. doi:10.1080/00103628809368027

Yildirim E (2007) Foliar and soil fertilization of humic acid affect productivity and quality of tomato Acta Agric Scandinavica. Section B Soil Plant Sci 57(2):182-186. doi:10.1080/09064710600813107

Zaller JG (2006) Foliar spraying of vermicompost extracts: effects on fruit quality and indications of late-blight suppression of field-grown tomatoes. Biol Agric Hortic 24(2):160-185. doi:10.1080/01448765. 2006.9755017

Zaller JG (2007) Vermicompost in seedling potting media can affect germination, biomass allocation, yields and fruit quality of three tomato varieties. Eur J Soil Biol 43:S332-S336. doi:10.1016/j. ejsobi.2007.08.020 